\title{
PENGARUH MATA KULIAH KEWIRAUSAHAAN DAN LOCUS OF CONTROL INTERNAL TERHADAP MOTIVASI BERWIRAUSAHA BAGI LULUSAN PRODI MANAJEMEN UNIHAZ BENGKULU
}

\author{
Fauzan, SE., M.M \\ Fakultas Ekonomi Universitas Prof. Dr. Hazairin,SH Bengkulu \\ Email: fauzanunihaz@gmail.com
}

\begin{abstract}
ABSTRAK
Penelitian ini bersifat eksplanatory risearach, karena melihat hubungan variabel pengetahuan kewirausahaan $\left(\mathrm{X}_{1}\right)$ dan locus of control $\left(\mathrm{X}_{2}\right)$ dengan motivasi berwirausaha (Y) serta pengujian hipotesa. Data yang digunakan dalam penelitian ini adalah data kuantitatif yang diperoleh dari hasil penyebaran kuesioner kerpada responden kemudian diolah kedalam analisa statistik.

Berdasarkan hasil analisa data dan pembahasan dapat disimpulkan bahwa (1) variabel pengetahuan kewirausahaan $\left(\mathrm{X}_{1}\right)$ dan Locus Of Control Internal $\left(\mathrm{X}_{2}\right)$ berpengaruh positif terhadap motivasi berwirausaha $(\mathrm{Y})$ lulusan prodi manajemen Unihaz Bengkulu. Informasi ini dapat dilihat dari persamaan regresi, korelasi berganda, determinasi, uji-t dan uji-f. (2) Variabel Locus Of Control Internal memberikan kontribusi yang lebih besar dibandingkan dengan pengetahuan kewirausaan dalam menumbuhkan motivasi berwirausaha bagi lulusan prodi manajemen Unihaz Bengkulu.

Sebagai saran, kedepan perlu inovasi-inovasi baru dalam penyampaian mata kuliah kewirausahaan, guna meningkatkan pengetahuan kewirausahaan kepada mahasiswa sebagai bekal mereka setelah menjadi sarjana. Perlu ditumbuh dan kembangkan rasa percaya diri dan keyakinan bahwa dengan berwirausaha kepada mahasiswa mereka mempunyai peluang suskes yang sangat besar.

Kata kunci : Pengetahuan Kewirausahaan, Locus Of Control Internal dan Motivasi Berwirausaha
\end{abstract}

\begin{abstract}
This research is explanatory risk, because it sees the relationship of entrepreneurial knowledge variables (X1) and locus of control (X2) with entrepreneurial motivation (Y) and hypothesis testing. The data used in this study are quantitative data obtained from the results of distributing questionnaires to respondents then processed into statistical analysis.

Based on the results of data analysis and discussion it can be concluded that (1) entrepreneurial knowledge variables (X1) and Internal Locus of Control (X2) have a positive effect on entrepreneurial motivation (Y) graduates of Unihaz Bengkulu management study program. This information can be seen from the regression equation, multiple correlation, determination, t-test and f-test. (2) Internal Locus of Control variables contribute more than entrepreneurship knowledge in growing entrepreneurship motivation for graduates of the management study program at Unihaz Bengkulu.
\end{abstract}


As a suggestion, in the future new innovations are needed in the delivery of entrepreneurship courses, in order to increase entrepreneurial knowledge to students as their provision after becoming a graduate. It is necessary to grow and develop a sense of confidence and the belief that by entrepreneurship to students they have a very high chance of success.

Key Words: Entrepreneurship Knowledge, Internal Locus of Control and Entrepreneurial Motivation

\section{Latar Belakang Masalah}

Paradigma lulusan Unihaz Bengkulu saat ini diharapkan tidak lagi berorientasi untuk mencari pekerjaan tetapi dapat menciptakan lapangan kerja minimal untuk dirinya sendiri. Oleh karena itu setiap program studi sudah mewajibkan mata kuliah kewirausahaan. Sejalan dengan diskripsi mata kuliah kewirausanaan Program Studi Manajemen Unihaz, yaitu bertujuan agar dapat mendorong mahasiswa untuk berwirausaha setelah menyelesaikan studinya dan mempersiapkan dengan pemahaman-pemahaman praktis.

Di negara kita saat ini pertumbuhan jumlah penduduk usia produktif tidak seimbang dengan jumlah lapangan kerja yang tersedia. Hal ini merupakan salah satu penyebab terjadinya pengangguran. Merujuk pada data Biro Pusat Statistik pada bulan Agustus 2018 menunjukkan bahwa pengangguran di Indonesia berada pada angka 7 juta (Kompas.com). Pengangguran besar-besaran di tingkat lulusan institusi perguruan tinggi (Abdullateef : 2017). Akar permasalahannya antara lain adalah paradigma berfikir lulusan yang masih berorientasi pada Jobseeker (Endah : 2017). Oleh karena itu jiwa kewirausahaan harus ditumbuh kembangkan pada diri mahasiswa.

Selain itu paradigma berfikir masyarakat dan orang tua lulusan sarjana masih menganggap kesuksesan seorang sarjana terletak pada cepatnya mereka mendapatkan pekerjaan. Baik di instansi pemerintah maupun swasta, dan mereka sama sekali belum dapat menghargai sarjana berwirausaha. Padahal berwirausaha mempunyai prosfek yang sangat baik itu dirinya, bahkan dapat membuka lapangan kerja bagi orang lain. Sesungguhnya hal ini jauh lebih bernilai dan bermanfaat.

Kewirausahaan/kewiraswastaan adalah suatu semangat, sikap, perilaku, dan kemampuan seseorang dalam menangani usaha atau kegiatan yang mengarah pada upaya mencari, menciptakan, menerapkan cara kerja, teknologi dan produk baru dengan meningkatkan efisiensi dalam rangka memberikan pelayanan yang lebih baik dan memperoleh keuntungan yang lebih besar. Bidang usaha atau perusahaan yang dibangun oleh seseorang dengan kepribadian tertentu (wiraswastawan/entrepreneur) sebagai alternative penyediaan lapangan kerja, minimal bagi si pemilik modal itu sendiri.

Locus of control didefinisikan sebagai keyakinan individu terhadap mampu tidaknya mengontrol nasib (destiny) sendiri (Kreitner dan Kinicki, 2005). Robbins dan Judge (2007) mendefinisikan sebagai tingkat dimana individu yakin bahwa mereka adalah penentu nasib mereka sendiri. Internal adalah individu yang yakin bahwa mereka merupakan pemegang kendali atas apa pun yang terjadi pada diri mereka, sedangkan ekternal adalah individu yang yakin bahwa apapun yang terjadi pada diri mereka dikendalikan oleh kekuatan luar seperti kesempatan dan 
keberuntungan ataupun bantuan pihak lain. Artinya bila lulusan program studi manajemen Unihaz memiliki locus of control internal yang dominan pada dirinya maka mereka akan berusaha semaksimal munkin untuk menjadi lebih baik dimasa yang akan datang. Salah satu cara yang ditempuhnya adalah dengan berwirausaha. Motivasi berwirausaha merupakan salah satu cerminan locus of control internal.

Dalam pengamatan awal peneliti masih rendahnya minat berwirausaha lulusan prodi manajemen Unihaz Bengkulu, padahal mereka telah dibekali dengan mata kuliah kewirausahaan. Hal ini menimbulkan pertanyaan apakah mata kuliah kewirausahaan ada relevansinya dengan semangat berwirausaha lulusan nantinya. Sejalan dengan revolusi industri 4.0 dirasakan sangat banyak membawa perubahan kearah kemajuan di satu sisi namun di sisi lain menibulkan konsekuensi pengurangan penggunaan sumber daya manusia karena digantikan oleh teknologi. Revolusi industri 4.0 menghadirkan usaha baru, lapangan kerja baru, profesi baru yang tidak terpikirkan sebelumnya. Sehingga hal tersebut membuka peluang bagi lulusan perguruan tingi untuk berwirausaha.

\section{Tujuan dan Manfaat Penelitian}

Secara umum penelitian ini bertujuan untuk membantu program pemerintah dalam mengatasi pengangguran di Indonesia. Secara spesifik tujuan penelitian ini untuk (1) Menjelaskan relavansi mata kuliah kewirausaan dengan motivasi berwirausaha (2) Tantangan lulusan dalam berwirausaha (3) Harapan lulusan akan materi dalam mata kuliah kewirausaan.

Manfaat dari penelitian ini diharapkan (1) Akan menumbuhkan minat berwirausaha bagi lulusan prodi manajemen (2) Pengembangan mata kuliah kewirausahaan.

\section{Tinjauan Pustaka}

Gerakan Kewirausahaan Nasional (GKN) telah dicanangkan oleh Presiden Republik Indonesia saat itu Bapak Susilo Bambang Yudhoyono tepatnya pada bulan Februari 2011. Dengan adanya GKN diharapkan generasi muda memiliki minat untuk menjadi wirausahawan dalam rangka meningkatkan pembangunan ekonomi, khususnya pengembangan kewirausahaan di Indonesia.

Pendidikan kewirausahaan menjadi faktor penting dalam menumbuhkan dan mengembangkan keinginan, jiwa dan prilaku berwirausaha dikalangan generasi muda karena pendidikan merupakan sumber sikap dan niat keseluruhan untuk menjadi wirausahawan sukses di masa depan (Fatoki, 2014). Pendidikan kewirausahaan merupakan usaha sadar yang dilakukan individu untuk menambah wawasan tetang kewirasuahaan (Gerba, 2015). Chimucheka (2013), menyatakan bahwa salah satu faktor pendorong pertumbuhan kewirausahaan di suatu negara terletak pada peranan universitas melalui penyelenggaraan pendidikan kewirausahaan.

Pengetahuan kewirausahaan mendukung nilai-nilai wirausaha terutama bagi lulusan prodi manajemen unihaz bengkulu, sehingga diharapkan menumbuhkan jiwa berwira-usaha. Mampu mengidentifikasi peluang usaha, kemudian mendayagunakan peluang usaha untuk menciptakan peluang kerja baru. Gorma (dalam Renny : 2015) menyebutkan tujuan pendidikan kewirausahaan adalah 
sebagai berikut : 1) belajar mengerti kewirausahaan, (2) belajar menjadi (entrepreneurial), dan (3) belajar menjadi wirausaha (entrepreneur). Tujuan mata pelajaran kewirausahaan adalah memberikan pengetahuan kewirausahaan, menanamkan keterampilan dan perilaku wirausaha, serta menumbuhkann semangat wirausaha.

Dalam rangka mendorong tumbuhnya jiwa kewirausahaan bagi para mahasiswa dan menciptakan lulusan yang mampu menjadi pencipta lapangan kerja (job creator), maka perlu diadakan pembinaan bagi mahasiswa agar mampu melaksanakan wirausaha (entrepreneur). Mahasiswa dibekali berbagai program dalam rangka menumbuhkan aktivitas wirausaha dalam lingkungan mahasiswa, seperti mata kuliah kewirausahaan (teori dan praktek), magang dan Kuliah Kerja Lapangan, yang diaharpkan dapat menjadi sumber inspirasi bagi mahasiswa setelah lulus nanti.

Gambaran ideal seorang wirausahawan menurut Alma (2010) adalah orang yang dalam keadaan bagaimanapun daruratnya, tetap mampu berdiri atas kemampuan sendiri untuk menolong dirinya keluar dari kesulitan yang dihadapi, termasuk mengatasi kemiskinan tanpa bantuan siapapun.

Locus of control atau diartikan sebagai persepsi seseorang tentang penyebab kesuksesan atau kegagalan dalam melaksanakan pekerjaannya. Seseorang memiliki kecenderungan internal locus of control memandang bahw segala sesuatu yang dialaminya, baik yang kurang berbentuk peristiwa, kejadian, nasib atau takdir disebabkan karena kendali dirinya sendiri. (Yosefhin Rika Ernima DKK : 2016 : 5)

Locus of control terkait dengan tingkat kepercayaan seseorang tentang peristiwa, nasib, keberuntungan dan takdir yang terjadi pada dirinya, apakah karena faktor internal atau faktor eksternal. Individu yang percaya bahwa peristiwa, kejadian, dan takdir disebabkan karena kendali dirinya sendiri disebut dengan internal locus of control. Sedangkan individu yang percaya bahwa peristiwa, kejadian, dan takdir disebabkan karena kendali dari faktor di luar dirinya disebut dengan eksternal locus of control (Robbins, 2005).

Sarafino \& Tomothy (2011) yang menyatakan, individu dengan internal locus of control yakin bahwa kesuksesan dan kegagalan yang terjadi dalam hidup tergantung pada diri sendiri. Orang yang mempunyai internal locus of control mempunyai keyakinan bahwa apa yang terjadi pada dirinya, kegagalan-kegagalan, keberhasilan-keberhasilannya karena pengaruh dirinya sendiri.

Minat wirausaha adalah keinginan, ketertarikan serta kesediaan untuk bekerja keras atau berkemauaan keras untuk berdikari atau berusaha memenuhi kebutuhan hidupnya tanpa merasa takut dengan resiko yang akan terjadi, serta senantiasa belajar dari kegagalan yang dialami. (Santoso : 2009).

Kewirausahaan merupakan pilihan yang tepat bagi individu yang tertantang untuk menciptakan kerja, bukan mencari kerja. Kewirausahaan dimaknai sebagai semangat, sikap dan perilaku atau kemampuan seseorang dalam melihat peluang dan menangani usaha (Astuti dan Yulianto, 2014)

Menurut Van Praag dan Versloot (2007), kewirausahaan sering dikaitkan untuk merangsang pertumbuhan ekonomi, inovasi, pekerjaan dan kreasi usaha. Penelitian empiris juga mendukung hubungan positif antara aktivitas kewirausahaan terhadap pertumbuhan ekonomi. 
Kewirausahaan merupakan suatu proses dinamis untuk menciptakannilai tambah atas barang dan jasa serta kemakmuran. Kewirausahaan sebagai kemampuan untuk menciptakan sesuatu yang baru dan berbeda. Peter F.Drucker(1994). Menurut Dan Steinhoff dan John F. Burgess (dalam Rintan Saragih 2017) wirausaha adalah orang yang mengorganisir, mengelola dan berani menanggung resiko untuk menciptakan usaha baru dan peluang berusaha. Secara esensi pengertian entrepreneurship adalah suatu sikap mental, pandangan, wawasan serta pola pikir dan pola tindak seseorang terhadap tugas-tugas yang menjadi tanggungjawabnya dan selalu berorientasi kepada pelanggan

I Gusti Lanang A. Dan Ni Made Purnami (2016) : Locus of control berpengaruh positif dan signifikan terhadap niat berwirausaha. hasil penelitian ini sejalan dengan rumusan hipotesis yang menyatakan locus of control berpengaruh positif terhadap niat berwirausaha. Hasil penelitian ini menunjukan bahwa semakin tinggi locus of control yang dimiliki mahasiswa, maka niat mahasiswa untuk berwirausaha akan meningkat.

Azwar (2013) menyatakan menumbuhkan jiwa kewirausahaan para mahasiswa perguruan tinggi dipercaya merupakan alternatif untuk mengurangi tingkat pengangguran, karena para sarjana diharapkan dapat menjadi wirausahawan muda terdidik yang mampu merintis usahanya sendiri karena dunia bisnis masa kini dan masa depan lebih mengandalkan knowledge dan intelectual capital, maka agar dapat menjadi daya saing bangsa, pengembangan wirausaha muda perlu diarahkan pada kelompok muda terdidik (intelektual).

Berdasarkan uraian di atas maka kerangka analisa dalam penelitian ini dapat digambarkan :

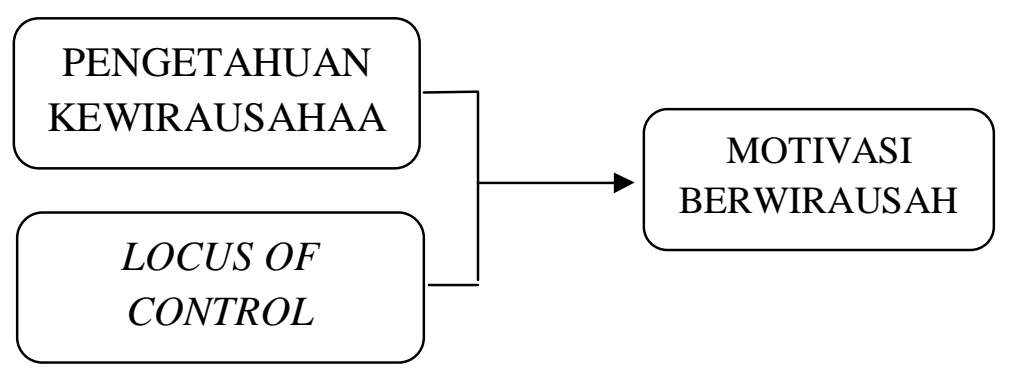

Sebagai hipotesa dalam penelitian ini adalah diduga adanya pengaruh pendidikan kewirausahaan dan locus of control terhadap motivasi berwirausaha bagi lulusan prodi manajemen unihaz Bengkulu baik secara parsial maupun secara simultan.

\section{Metode Penelitian}

Penelitian ini bersifat eksplanatory risearach, karena melihat hubungan variabel pengetahuan kewirausahaan $\left(\mathrm{X}_{1}\right)$ dan locus of control $\left(\mathrm{X}_{2}\right)$ dengan motivasi berwirausaha (Y) serta pengujian hipotesa. Data yang digunakan dalam penelitian ini adalah data kuantitatif yang diperoleh dari hasil penyebaran kuesioner kerpada responden kemudian diolah kedalam analisa statistik. 
Populasi dalam penelitian ini adalah lulusan prodi manajemen Unihaz Bengkulu tahun akademik 2015-2016 s.d 2017-2018 berjumlah 249 orang lulusan. Teknik pengambilan samapel probability sampling, dengan metode proportionate stratified random sampling, yaitu sampel diambil $30 \%$ dari jumlah lulusan setiap tahunnya $\quad(30 \% \times 87+30 \% \times 75+25 \% \times 87)=70$ (dibulatkan) orang lulusan.

Analisa yang digunakan dalam penelitian ini adalah Analisis (1) regresi linear berganda, yang digunakan untuk mengetahui besarnya pengaruh antara variabel pengetahuan kewirausahaan $\left(\mathrm{X}_{1}\right)$ dan locus of control internal $\left(\mathrm{X}_{2}\right)$ dengan variabel motivasi berwirausaha (Y). Menurut Sugiyono (2013:269) persamaan regresi linear berganda dengan dua variabel independen adalah sebagai berikut : $\mathrm{Y}=\mathrm{b}_{0}+\mathrm{b}_{1} \mathrm{X}_{1}+$ $\mathrm{b}_{2} \mathrm{X}_{2}+\mathrm{e}(2)$ korelasi berganda untuk melihat tingkat keeratan atara variabel-varibel independen dengan variabel dependent. (3) koefisein determinasi akan memberikan informasi seberapa besar persentase variasi variabel bebas yang digunakan dalam model mampu menjelaskan variasi variabel terikat. (Prayitno : 2013 : 143). (4) Pengujian hipotesis yang digunakan dalam penelitian ini ialah uji signifikansi simultan atau uji statistik $\mathrm{F}$ dan uji signifikansi parameter individual atau uji statistik t. Uji F untuk menunjukkan apakah semua variabel independen secara simultan berpengaruh pada variabel dependen (Utama, 2009:69). Uji t dipakai untuk mengetahui seberapa besar pengaruh dari variabel independen secara parsial terhadap variabel dependen (Utama, 2009:68).

\section{Analisa dan Pembahasan}

Berdasarkan hasil analisis SPSS diperoleh tabel sebagai berikut :

Coefficients $^{\mathrm{a}}$

\begin{tabular}{|l|r|r|r|r|}
\hline \multirow{2}{*}{ Model } & \multicolumn{2}{|c|}{$\begin{array}{c}\text { Unstandardized } \\
\text { Coefficients }\end{array}$} & \\
\cline { 2 - 3 } & \multicolumn{1}{|c|}{$\mathrm{B}$} & \multicolumn{1}{|c|}{ Std. Error } & \multicolumn{1}{c|}{ T } & \multicolumn{1}{c|}{ Sig. } \\
\hline $1 \quad$ (Constant) & 14.900 & 1.512 & 9.855 & .000 \\
$\quad$ Pengetahuan Kewirausahaan & .126 & .062 & 2.030 & .046 \\
& .208 & .079 & 2.642 & .010 \\
\hline
\end{tabular}

a. Dependent Variable: Motivasi Berwirausaha

\begin{tabular}{|l|r|r|r|r|}
\hline $\begin{array}{l}\text { Mode } \\
1\end{array}$ & $\mathrm{R}$ & \multicolumn{4}{|c|}{ Model Summary $^{\mathbf{b}}$} \\
\hline 1 & $.466^{\mathrm{a}}$ & \multicolumn{1}{c|}{$\begin{array}{c}\text { Adjusted R } \\
\text { Square }\end{array}$} & $\begin{array}{c}\text { Std. Error of } \\
\text { the Estimate }\end{array}$ \\
\hline
\end{tabular}

a. Predictors: (Constant), Locus Of Control, Pengetahuan Kewirausahaan

b. Dependent Variable: Motivasi Berwirausaha

CR MT Vol 2 No. 1 ISSN 2621-10992 


\begin{tabular}{|l|r|r|r|r|r|}
\hline \multicolumn{1}{|l|}{ ANOVA $^{\mathbf{b}}$} & \multicolumn{1}{l|}{ Sum of } \\
Model & Squares & Df & Mean Square & F & Sig. \\
\hline $1 \quad$ Regression & 18.658 & 2 & 9.329 & 9.272 & $.000^{a}$ \\
Residual & 67.413 & 67 & 1.006 & & \\
Total & 86.071 & 69 & & & \\
\hline
\end{tabular}

a. Predictors: (Constant), Locus Of Control, Pengetahuan Kewirausahaan

b. Dependent Variable: Motivasi Berwirausaha

Persamaan regresi $\mathrm{Y}=14,900+0,126 \mathrm{X}_{1}+0,208 \mathrm{X}_{2}$ persamaan tersebut menunjukkan bahwa apabila pengetahuan kewirausahaan ditingkatkan satu satuan akan menaikan motivasi berwirausaha 0,126 satuan, dengan asumsi bahwa locus of control internal konstan. Kemudian bila ditingkatkan locus of control internal satu satuan maka akan dapat meningkatkan motivasi berwirausaha sebesar 0,208 satuan, dengan asumsi pengetahuan kewirausahaan konstan. Hasil uji parsial t-test diperoleh informasi t-hitung adalah 2.642 dengan tingkat significant 0,010 jauh lebih kecil dari 0,05. Ini artinya locus of control internal berpengaruh positif dan significant terhadap motivasi berwirausaha.

Dilihat dari persamaan regresi di atas dapat diketahui bahwa kontribusi variabel locus of control internal terhadap motivasi berwirausaha lulusan prodi manajemen Unihaz Bengkulu lebih dominan. Hal ini sejalan dengan beberapa penelitian sebelumnya. Menurut Crider (dalam Ghufron \& Risnawati, 2014) individu yang memiliki internal locus of control mempunyai ciri-ciri sebagai berikut : (1) Suka bekerja keras (2) Memiliki inisiatif tinggi (3) Selalu berusaha menemukan pemecahan masalah (4) Selalu mencoba berpikir seefektif mungkin (5) Selalu mempunyai persepsi bahwa usaha harus dilakukan jika ingin berhasil.

Individu yang memiliki internal locus of control jika mengalami kagagalan, mereka akan menyalahkan dirinya sendiri karena kurangnya usaha yang dilakukan. Begitu pula dengan keberhasilan, mereka akan mezrasa bangga atas hasil usahanya. Hal ini akan membawa pengaruh terhadap tindakan selanjutnya pada masa yang akan datang, yakni mereka yakin akan mencapai keberhasilan apabila berusaha keras dengan segala kemampuannya. Locus of control internal tmengacu pada persepsi individu tentang kesuksesan dan kegagalan. Seseorang yang memiliki pengendalian yang tinggi cenderung memiliki visi yang jelas dan rencana bisnis jangka panjang. Semakin tinggi locus of control internal maka semakin tinggi pula motivasi berwirausaha seseorang lulusan prodi manajemen Unihaz Bengkulu.

Pengetahuan kewirausahaan berpengaruh positif terhadap motivasi berwirausaha yang ditunjukkan oleh angka 0,126. Nilai ini menunjukkan bahwa pengetahuan kewirausahaan lebih kecil pengaruhnya terhadap motivasi berwirausaha bila dibandingkan dengan locus of control internal.

Hasil penelitian ini sejalan dengan penelitian yang dilakukan oleh I Gusti Lanang dan Ni Made Purnami yang berjudul Pengaruh Pendidikan Kewirausahaan, Self Efficacy dan Locus Of Control pada Niat Berwirausaha. Namun kalau dilihat 
dari uji parsial t-test, dimana t-hitung sebesar 2,030 dengan tingkat sinificat 0,046, hampir mendekati 0,05 artinya pengaruh pengetahuan kewirausahaan terhadap motivasi berwirausaha sangat lemah.

Korelasi berganda hasil analisa adalah 0,466 artinya hubungan keeratan antara variabel pengetahuan kewirausahaan dan Locus Of Control Internal cukup kuat karena berada pada angka 0,40 - 0,599 (Sugiyono : 2013). Koefisien diterminasi ( $R$-Square) adalah 0,217 artinya 21,70\% Pengetahuan Kewirausahaan dan Locus Of Control Internal dapat mempengaruhi motivasi berwirausaha lulusan prodi manajemen, sedangkan 78,30\% dipengaruhi oleh variabel-variabel lain diluar variabel yang kami teliti. Dengan demikian penelitian dibidang ini masih memerlukan penelitian lebih lanjut dengan variabel-variabel independen yang lain.

Hasil uji simultan f-test menunjukkan angka 9,272 dengan tingkat significant 0,000 lebih kecil dari 0,05. Artinya secara simultan (bersama-sama) Pengetahuan Kewirausahaan dan Locus Of Control Internal dapat mempengaruhi motivasi berwirausaha lulusan prodi manajemen Unihaz Bengkulu. Sejalan dengan koefisien regresi dan uji parsial di atas hanya satu variabel yang dominan dan pengaruh yang significant yaitu Locus Of Control Internal.

\section{Simpulan dan Saran}

Berdasarkan hasil analisa data dan pembahasan dapat disimpulkan bahwa (1) variabel pengetahuan kewirausahaan $\left(\mathrm{X}_{1}\right)$ dan Locus Of Control Internal $\left(\mathrm{X}_{2}\right)$ berpengaruh positif terhadap motivasi berwirausaha (Y) lulusan prodi manajemen Unihaz Bengkulu. Informasi ini dapat dilihat dari persamaan regresi, korelasi berganda, determinasi, uji-t dan uji-f. (2) Variabel Locus Of Control Internal memberikan kontribusi yang lebih besar dibandingkan dengan pengetahuan kewirausaan dalam menumbuhkan motivasi berwirausaha bagi lulusan prodi manajemen Unihaz Bengkulu.

Sebagai saran karena pengetahuan kewirausahaan pengaruhnya masih kurang significant terhadap motivasi berwirausaha, maka kedepan perlu inovasi-inovasi baru dalam penyampaian mata kuliah kewirausahaan. Misalnya praktek kewirausahaan perlu ditingkatkan, magang ke unit-unit usaha dan kerajinan masyarakat, seminar-seminar atau diskusi dengan menjadikan wirausahawan yang sukses sebagai narasumber dan kerjasama dengan pihak-pihak yang terkait guna meningkatkan pengetahuan kewirausahaan kepada mahasiswa sebagai bekal mereka setelah menjadi sarjana.

Locus Of Control Internal telah memberikan pengaruh yang significant, maka sipatnya hanya perlu ditumbuh dan kembangkan rasa percaya diri dan keyakinan bahwa dengan berwirausaha mereka mempunyai peluang suskes yang sangat nbesar. Harus tertanam rasa bangga dalam diri mahasiswa bahwa setelah lulus nanti menjadi wirausaha jauh lebih baik daripada bekerja dengan pihak lain.

\section{REFERENSI}

Alberti F, Sciascia dan Poli. 2004. Entrepreneurship Education: Notes on an Ongoing Debate. Disampaikan pada Proceedings of the 14th Annual International 
Entrepreneurship Conference, University of Nopoli, Federico II, Italy, 4-7 Juli 2004.

Alma,Buchari, 2010. Kewirausahaan(edisi revisi). Bandung: CV Alfabeta.

Astuti, T.P dan Yulianto. 2014. Pengaruh Faktor Demograpi Psikologis dan Kontekstual Terhadap Niat Kewirausahaan Pada Mahasiswa (Studi terhadap Mahasiswa Universitas Setia Budi Surakarta), Seminar Nasional dan Call For Papper Program Studi Akuntansi-FEB UMS

Azwar, Budi. 2013. Analisis Faktor-faktor yang Mempengaruhi Niat Kewirausahaan (Entrepreneurial Intention). Studi Terhadap Mahasiswa Universitas Islam Negeri SUSKA Riau. Menara, 12(1): 12-22.)

Chimucheka, Tendai. 2013. The Impact of Entrepreneurship Education on the Establishment and Survival of Small, Micro and Medium Enterprises (SMMEs). Journal Economics, 4(2): 157-168.

Drucker, P.F , 1994, Innovation and Entrepreneurhip, New York:Harpercollins Publisher

Fatoki, Olawale, 2014. The Entrepreneurial Intention of Undergraduate Students in South Africa: The Influences of Entrepreneurship Education and Previous Work Experience. Mediterranean Journal of Social Sciences, 5(7): 294-299.

Gerba, Dugassa Tessema. 2012. Impact of entrepreneurship education on entrepreneurial intentions of business and engineering students in Ethiopia. Journal of Economic and Management Studies, 3(2): 258-277.

Ghufron, M. \& Rini Risnawati, 2014. Teori-teori psikologi. Yogyakarta: Ar-Ruzz Media Group.

I Gusti Lanang Agung Adnyana Ni Made Purnami, 2016. Pengaruh Pendidikan Kewirausahaan, Self Efficacy dan Locus Of Control Pada Niat Berwirausaha (EJurnal Manajemen Unud, Vol. 5, No. 2, 1160-1188.

Priyatno. 2013. Mandiri Belajar Analisis Data Dengan SPSS. Jakarta, Mediakom.

Renny Dwijayanti. 2015, Jurnal Ekonomi Pendidikan dan Kewirausahaan. Universitas Negeri Surabaya Vol 3 No. 1.

Rintan Saragih, 2017. Membangun Usaha Kreatif, Inovatif dan Bermanfaat Melalui Penerapan Kewirausahaan. Jurnal kewirausahaan Vol 3 no 2 Desember. Medan STIE LMII.

Robbins, S.P, 2005, Organizational Behavior:Concepts, Controversies, Applications.Twelfth Edition. New Jersey. Prentice Hall International.

Rostiani, R. 2008. Intensi Kewirausahaan Mahasiswa: Studi Perbandingan Antara ndonesia, Jepang Dan Norwegia. Jurnal Ekomoni dan Bisnis. Vol. 23 No.421

Santoso. 2009. Lingkungan Tempat Tinggal Menentukan Minat Berwirausaha.FKIP. UNS (Laporan Penelitian). Surakarta :UNS

Sarafino, Edward P., \& Tomothy W. Smith. 2011. Health Psychology Biopsychosocial Interactions. Edition 7th. Ebook. 
Sugiyono. 2013. Metode Penelitian Bisnis. Bandung: Alfabeta.

Utama, S. M. 2009. Aplikasi Analisis Kuantitatif (Edisi Ketiga). Denpasar: Sastra Utama.

Van Praag, C. Mirjam and Peter H Versloot. 2007. A Review of Recent Research: What Is the Value of Entrepreneurship?. Disampaikan pada IZA Discussion Paper, University of Amsterdam and Tinbergen Institute, Netherlands, Agustus 2007.

Wiriani, W., Piatrini, S.Y dan Ardana. 2013. Efek Moderasi Locus of Control pada Hubungan Pelatihan dan Kinerja pada Bank Perkreditan Rakyat di Kabupaten Badung. Jurnal Ilmiah Akuntansi dan Bisnis, 8(2): 99-105.

Yosefhin Rika Ernima dkk. 2016. Jurnal Pendidikan Ekonomi dan Bisnis Vol. 4 No. 2 Oktober 2 